\title{
Impact of the Rural Coping Poverty Feminization Program
}

\author{
Alifiulahtin Utaminingsih ${ }^{1}$, Irma Fitriana Ulfah $^{2}$, Sumi Lestari ${ }^{3}$ \\ \{alifiulathin@ub.ac.id ${ }^{1}$,irmafittt@gmail.com², sumi-lestari@ub.ac.id ${ }^{3}$ \} \\ Universitas Brawijaya, Indonesia ${ }^{1,2,3}$
}

\begin{abstract}
This study aims to analyze of rural coping poverty feminization program in economic area, especially the poor female householder, but also analyze the supporting and inhibiting factors within the Feminization of Poverty Alleviation of Jalin Matra Program in Tulusbesar Village, Tumpang District, Malang Regency, East Java, Indonesia. This is a program launched by the Governor of East Java in 2014-2019 which aims to empower the poor society in East Java (Pergub Number 5 in 2018). Tulusbesar Village is chosen due to the fact Malang Regency is in the highest rank of the poor society among East Java. The method used descriptive-qualitative, in which the primary data is taken with interviews 50 informants were Poor Female Householder. The empowerment of KRTP is done through 3 stages, to be exact: responsiveness or behavior development, values transformation and intellectual enrichment. The results showed that there were 70 percent or 35 KRTP that succeeded in developing their business, with only 3 KRTP or 6 percent where their businesses had not succeeded yet. The KRTP who did not succeed in developing their business were $12 \mathrm{KRTP}$ or 24 percent. The women empowerment at the Tulusbesar Village can be said to be successful due to the most of the KRTP beneficiaries of Jalin Matra succeed or could develop their business well and need to be improved according to their potential and capabilities.
\end{abstract}

Keywords: Gender, Female Householder, The Feminization of Poverty, The Women Empowerment.

\section{Introduction}

Poverty is a condition where someone is unable to fulfill his basic needs, such as: clothing, food, shelter and proper health. According to the National Development Planning Agency, poverty is a circumstance of inadequacy due to a situation that cannot be avoided by someone with the strength he has.

In Java, there are three provinces which are among the three largest poor societies in Indonesia. East Java is the province that ranks first for the percentage of poor people in 2017 which are 4405 people (16.55) from 26583 people in Indonesia. While the second rank is Central Java which is $15.7 \%$ and third is West Java at $14 \%$ Very Poor Household Aid. Based on the results of the survey, East Java was in the first rank of poverty in Java.

Empowerment programs are an effort in poverty reduction which is provided by the government of East Java Province. Jalin Matra Program consists of three types, those are: Very Poor Household Aid, Feminization of Poverty Reduction and Nearly Poor Households. The aim of these three types of program is to empower the poor in several kinds of goals. 
This focus of this research is to analyze the reduction of poverty feminization in Jalin Matra Program, for the reason that among the three program targets, empowerment for poor rural women is more essential [1]. First, the PK2 of Jalin Matra Program which focuses on Rumah Tangga Hampir Miskin which actually could be able to still support their families. Therefore, as it is compared to the other two targets, it is still less critical. Second, the aid to help Rumah Tangga Hampir Miskin has been carried out by the government programs such as Bantuan Langsung Tunai (BLT), PKH, BLNT, KIS and others. Third, the main target of Jalin Matra program is for the very poor female householders. This is due to the fact that female householders are more vulnerable to poverty, because she carries the family's economic burden and more likely to experience discrimination on the access to financial capital, wages and property ownership.

Those who previously relied on the role of men in providing for their families must or are forced to take on the role as the head of their household. The Feminization of Poverty Reduction in Jalin Matra Program is committed in carrying out an inclusive people-centered development, encouraging people's participation (participatory-based development), economic growth which is aimed for the poor society (pro poor growth) and gender mainstreaming [2].

The focus on KRTP is intended for women, especially groups of poor women, so they can be freed from the snares of poverty [3]. This program has been implemented in 25,094 female householders, 913 villages and 37 regencies or cities. This research is taken a place in Tulusbesar Village, Tumpang Subdistrict, Malang Regency, because based on Jalin Matra coordination meeting data in 2018 which shows that Malang District is in the first rank for poor population in East Java.

Tulusbesar Village, Tumpang Subdistrict, Malang Regency is the research location which being the object of community empowerment carried out by East Java Province. There are several underlying reasons. First, the condition of poverty in that village can be considered alarming. This is because Tulusbesar Village has the highest position in terms of poverty in Malang Regency, it is also one of the highest villages which has the highest number of poor female householder in Malang Regency.

The factors that cause poor women could be classified into five. First, being widow by death in which women become widows because their husbands have passed away. The percentage of widows for the reason that their husbands died was 31 KRTP (55 percent). Second, being widows due to divorce, amounting to 10 KRTP (18\%). Third, being widows because they were abandoned by the husband which was happened because of mismatch or conflict within the family, so the husband left or abandoned his wife, were about 8 KRTP (14\%). Fourth, poor women which is caused by the physical illness of the husbands, then the duties of the head of the household are charged to her was 5 KRTP (9\%). Fifth, women with disabilities husbands, in which the husbands are unable to become the head of households in their families and provide the family needs due to the physical disability of 2 KRTP (4\%).

Third, psychologically, women who are charged as the householder would feel it is dense. The social culture shows that men are charged to be the head of the household and provide a living for their wives and children. However, for the sincere poor female householders in Tulusbesar Village which used to be housewives only, forced themselves to do double role, namely as housewives and at the same time seek an earning for their families. This burden is combined with the lack of human resources, so that those women will face several difficulties to develop their ability. Due to this phenomenon has led to the occurrence of poverty feminization, the aid given by the government such as the financial capital and Jalin Matra Program are expected to bring a positive impact for the poor family of female householders. 
This study uses socio-cultural and economic approaches from sociocultural and psychological aspects in analyzing the poverty phenomenon of rural women with its various causal factors, a case study on the poor female householders, by the use of qualitativedescriptive analysis. Therefore, this research problem is as follow: How is the rural women empowerment carried out by the government in order to cope the poverty feminization that occurs within the poor female householders in Malang Regency? Then, what are the supporting and inhibiting factors on the empowerment of the rural poor female householders in Malang Regency?

\section{Theoretical Framework}

\subsection{Gender Theory}

The term gender was first introduced by Stoller (1968) to separate the details of human roles and functions based on the sociocultural nature definition and another definition which is derived from biological characteristics. Ahimsa Putra divides the term gender in two terms, such as: (1) gender as a imported term with certain meanings, which are not widely understood and emerged difference perspective in understanding the meaning of gender itself, which somehow are likened with sex; (2) gender as a socio-cultural phenomenon, so that gender is a social awareness constructed by the social culture [4].

The term of gender which was written by Lips is interpreted as "cultural expectation for women and men". For example, women are known for being gentle, sensitive, beautiful, nurturing and serving men. While men are considered as a hard-worker, strong, rational, masculine, powerful and look after the women [5].

This research uses nurture theory as the basis of research theory, which is caused by nurture theory emphasizes that men and women are not determined by biological factors but on the socio-cultural construction that attempt to empower women in all kind of fields. This theory considers the distinction among men and women is as a result of socio-cultural construction rather than a natural gift as it creates different roles, functions and responsibilities. In the sociological study, this theory emerged feminist movement that focuses on women empowering activities and optimally accommodated women potentials, so they would be able to be independent.

Rural women usually live in low-income society with limited access of jobs and relatively get a lower wage than men. Related to this issue, Erdianto explained that "Women still experience discrimination in several fields with varied forms, such as: acts of violence, social stigma, domestication and marginalization".

\subsubsection{Stage of Community Empowerment}

Etymologically, the word empowerment came from the basic word "power" which means strength or ability. Hence, empowerment is a process towards empowering or gain power, strength and ability, a process of giving way the capabilities from a powerful group for the powerless group [6]. The stages that must be passed intended for community empowerment are as follows: (1) The awareness and formation of behavior stage towards conscious and thought fulminans as a result of society necessity for self-capacity growth; (2) The transformation phase is about ability alteration of knowledge understandings, basic skills 
which is needed to have a good insight and entrepreneurship capability, so people know how to take parts within the development process; (3) The stage of increasing intellectual abilities, specifically skills, so people could form an innovative initiatives and capabilities which leads to independence.

The word "process" within an empowerment term means as a real action that is done in several stages to change the less-empowered society towards a better empowering. The word "giving" power has the meaning that it is the community itself which being the initiative source for the empowerment. People seek, do, pursue or ask to be empowered by other parties who have more power. The word "giving" itself is also an initiation that comes from a party which could provide a better power to the community, such as the government, the private sector or even both.

In line with these thoughts, Aziz defines community empowerment as follows:

"Community empowerment is a process in which communities, especially those who lack of access to the development resources, are encouraged to increase their independence in developing their lives. Community empowerment is also a continuous cycle of process, a participatory process, where community members work together in formal and informal groups to knowledge and experience sharing and trying to achieve the common goals. Thus, community empowerment is a process towards empowering and independence" [7].

Referring to the understanding above, it can be concluded that: empowerment is an effort to improve the ability of the community or the people who do not have a power to develop their potential, so that the community can improve their abilities and participate through various activities. Therefore, empowerment is about an accomplishment to form the individuals and communities to be independent. The meaning of independent itself refers to the independence of thinking, acting and controlling what they do. Within the effort to achieve the community independence, a process is needed, through a gradual and continuous learning process, so that people's abilities will increase over time.

\subsubsection{The Purpose of Community Empowerment}

The goal of empowerment is to form independence among the individuals and society. The meaning of the word independent refers to the independence of thinking, acting and controlling what people do. In achieving community independence, a process is needed, through a gradual learning process so that the ability of the community will increase over time. Therefore, the empowerment activities must cover all kind of aspects within people's lives which liberate them from the community groups with power domination, both in the economic, political and socio-cultural sectors.

The empowerment goals within economic field are to create strong, big, independent and highly competitive economy. While the political sector aims to strengthen the society in the decision-making process among nation and state life, while the socio-cultural sector aims to strengthen the people through increasing, upholding the values, ideas, norms and promoting the realization of social organizations. Therefore, it can be concluded that the purposes of empowerment are to empower the community particularly as of poverty, inequality, backwardness and powerlessness through three fields to be precise politics, economics and socio-culture. Consequently, poverty is closely related to empowerment for the reason that the purpose of empowerment is to empower the poor. 


\subsection{Poverty Theory}

Conceptually, poverty is full stated by Chambers, who explained that the essential problem of poverty actually lies in what is called as deprivation trap. The World Bank stated that poverty is a lack of prosperity condition. Meanwhile, Levitan argued that poverty is a lack of needed goods and services in order to achieve a decent standard of living. Schiller's thinking mostly as same as Levitan, where he argued that poverty is an inability to obtain adequate goods and a service to fulfill the limited social needs [8].

There are four forms of poverty, namely: absolute poverty's kind of poverty which is caused by the inability to fill the minimum living needs, relative poverty, cultural poverty and structural poverty. Based on the contributory factors of poverty, it is connected with the vicious circle of poverty. The vicious circle of poverty was declared by Nurkse. He argued that "a poor country is poor because it is poor" [9].

Therefore, this research uses the theory of marginal poverty. Marginal theory assumes that poverty occurs due to the kind of socialized destitution culture among the marginalized communities. The main figure of this theory is Oscar Lewis with his concept which is called as culture poverty, he explained that poverty is a culture caused by a lasting economic deprivation from time to time. Then, the cultural confinement poor society can be comprehended through less participatory characteristics among development or activities, because most of them are illiterate, low-level of education and lack of financial capital.

\subsubsection{Poverty Feminization}

Moghdam explained that the disadvantage of poor women is a new problem, because if poverty is perceived as a denial of human rights, it must be recognized that the poor women among the poor society certainly suffer double their basic rights disavowal [10]. The intended human rights disavowal is gender inequality and the poverty itself. That is what Diana Pearce called as the term feminization of poverty, so women who live in poverty are likely to be far more numerous and highly increased than men [11].

According to Friedman, poverty could be understood as an opportunity discrimination to formulate and gain social power in the form of assets, financial resources, social political organizations, social networks, goods or services, knowledge, skills and information. While according to Brindley, poverty could be defined as an inability to get an item or service that is adequate to meet limited social needs [12]. Most of the definitions of poverty usually intertwining the concept of poverty with an economic concept. Meanwhile, the feminization of poverty according to Scott is a term to define a certain economic unsteadiness for the women who single-handedly support the family financial life [13]. Women who experience poverty and must bear the economic burden of divorce, being left behind (abandoned by their husbands), disability or the death of their husbands. Therefore, the poor women in this research can be interpreted as the condition of a woman or female head of household in a poor family who works to meet the economic needs of her family.

The inability to fulfill the daily basic needs push the poor women to do everything they can to survive. This method was stated by Scott [14] with a survival mechanism. The survival mechanism which is done by poor women consists of three aspects:

a) Reducing the food costs by eating once a day and switching it to the lower-quality foods.

b) Spending time with subsistence self-help alternatives, such as: small-scale selling, working as a handyman, freelance daily laborer or migration to get a job. This 
method could involve all the resources within the poor households, especially the wife who acts as the main laborer or additional breadwinner to replace the husband.

c) Request help from social linkages, such as: relatives, neighbors or use relationships with the patron. The definition of patron itself is the people who are in a position to help their clients.

\section{Research Methods}

This study uses a qualitative-descriptive method to explain and analyze a phenomenon of poverty feminization and its causes in depth. Coping the poverty feminization of Jalin Matra Program in Tulusbesar Village is an approach-based research to the community as a phenomenon as well as the subject and object of research. Bogdan and Taylor explained that descriptive method is research procedures that produce data in the form of written or oral words from people and observable behavior. The data are obtained as of interviews, photos, personal documents, observations and other official documents [15].

The focus of this research was on the role of provincial, regency and local district governments in empowering the poor 50 KRTPs through the PFK Program, then analyze the supporting and inhibiting factors of program implementation.

\section{Results and Discussion}

The stage of empowering the poor KRTP in Tulusbesar Village, Tumpang-Malang District is done through 3 (three) stages. First, they are being widows the stage of awareness and behavior formation. At this stage, not only the KRTP who get the behavior formation or socialization, but also the entire government below the provincial government. At this stage, KRTP does not have any participation at all. The efforts to shape the awareness and behavior carried out by the government and village facilitators by conducting an intensive community consultation by providing socialization and visit all of the KRTP homes with motivation and business ideas.

Second, they are being widows to divorce amounting to 10 KRTP (18\%) the transformation phase is the intermediate stage of the KRTP which initially did not yet have awareness towards a better consciousness. At this stage, the initial KRTP used to show low participation. The transformation phase was marked by the willingness of the KRTP to create a business idea. The efforts of the government and village facilitators are to help in providing business ideas. One of the efforts made by KRTP itself is a community group leadership (POKMAS) to contribute the society in creating business ideas. In addition, the village government also escorting the KRTPs with productive age from disbursing funds to spending business capital as needed.

Third, the final stage of empowerment is the intellectual improvement phase. This stage can be said to be successful if KRTP has been independent to develop their own business. There are $70 \%$ or 35 KRTP who succeed in developing their business. The other KRTP which only half of their business is successful or has two types of businesses, but only one business that succeeds were three KRTP or $6 \%$. Whereas there were 12 KRTPs or $24 \%$ failed in developing their business. It can be said that empowerment through the coping of poverty 
feminization in Jalin Matra for the poor women in Tulusbesar Village is successful because more than $70 \%$ of the beneficiaries can be independent

One of the succeeded KRTPs with a grocery business was Mrs. Tunah. She is a 60-yearold widow whose husband died 22 years ago, living alone with a small grocery business to provide the life of three kids. After getting the aid from the government, her business turned to be bigger with various products, plus selling fried food. The fried food is sold from $05.00 \mathrm{a} . \mathrm{m}$. to 07.00 a.m. After the fried food was sold out, the stall opened. The prior gross income earned was around one million per week, but it increased into three million per week right after the business got bigger. This income turned her into an independent KRTP who could help in providing the grandkids allowance. She is very grateful for the presence of this program which greatly helps her financial which can fulfill the needs of her families.

Mrs. Muriyam is also one of 35 KRTPs who have succeeded in developing her business. She has sold rice cake since 1978 until she gained succeed nowadays. Mrs. Muriyam's husband passed away 22 years ago, but luckily, she had started her business before her husband died so she could help the family's economy. Before got an aid from the government, she could earn 700 thousand rupiah per week. After the assistance, she could develop her business with another new utensils, such as: large pots, wood as the fuel and banana leaves, so she expanded the business with some new orders. Mrs. Muriyam's gross income has increased to 1.7 million per week. She usually sells her products at the Tumpang Market from 6a.m up to 9 a.m. She could sell $10 \mathrm{~kg}$ of rice cake on her daily basis.

One of the KRTPs that started a new business and classified as successful was Mrs. Suriati. She is a divorcee for 10 years. To cover her family needs, she has opened a food stall in Tulusbesar Village. The aid which around 2.5 million was functioned to sell daily meals. But then, because there are so many competitors, the she decided to open a rice cake stall. Her stall is in front of Tumpang Post Office which opens from 7-10 in the morning. The net income achieved from selling rice cake is around 700 thousand per week. These earnings can be used to renovate the house, pay the kids' tuitions and another daily needs.

Besides being an entrepreneur, there are another KRTPs who succeeded and being independent in raising stocks. Mrs. Siani became a KRTP because her husband died 20 years ago, she has been supporting her family by working as a domestic helper with a daily wage about Rp. 40,000 since her husband death. For two years, the goats increased into another six goats. Three of the seven goats were sold to make a hut for his son, Giono. Although the cattle were not run by Mrs. Siani herself, Mrs. Siani's children were able to manage it well, even take care and buy medicine when the stocks got sick. Here is the statement:

"I used to buy a pair of goats, the first breed was a male goat, the second batch were born 3 males, then the third batch were 2 females then the other one died. So now there are 8 goats. As they seen get pregnant again now, I hope these stocks could getting bigger and increased".

Mrs. Siti Kholifah whom the leader of the Mawar Pokmas also has a fairly successful business. He is the widow with a kid who had been in an unofficial marriage but got abandoned for 11 years by her husband. She is a person who has a lot of experiences and skills. Before she started to sell fried rice, there have been many kinds of work she had tried, such as: working in a candy factory, cooking at a depot, pharmacy in the cosmetics department and then has started the fried rice stall eight years ago. In 2011 Mrs. Kholifah received Jalin Kesra assistance, then 2016 was added by Jalin Matra. Then, she could develop her business 
into a bigger place. The net income from her business increased from Rp. 340.000 per week to Rp. 680.000 per week after receiving the aid. In addition to the main income.

\section{Conclusion}

The conclusions in this research are based on three indicators from the Empowerment Stages. The first stage was the stage of awareness and behavior formation. At this stage, not only the KRTPs who got the socialization of behavior formation, but also the entire governments under the provincial government. At this phase, KRTPs did not have any participation at all. The efforts to raise the awareness and form the behavior carried out by the government and village facilitators are by conducting meetings to provide socialization and visit all of the KRTPs houses with motivation and business ideas sharing.

The second stage was the transformation stage, which is the intermediate stage of the KRTP which initially has no awareness towards consciousness. At this step, KRTP began to show low participation. The transformation phase was marked by the willingness of the KRTP to create a business idea. The efforts of the government and village facilitators are to help the society to provide business ideas. The efforts made from KRTP group itself was by creating 'Kelompok Masyarakat' to help the other communities in creating business ideas. In addition, the village government also accompanied the KRTPs starting from disbursing funds to spending business capital. The government and village facilitators will further facilitate the elderly KRTP to spend business capital.

The final stage of empowerment was the stage of intellectual improvement. This stage can be said to be successful if KRTP has been independent and could be able to develop their businesses. There were $70 \%$ or 35 KRTP who succeed in developing their business. KRTP which part of their business were succeeding or has two types of businesses, but only one business that succeeded were three KRTP or $6 \%$. Whereas the KRTPs who were not successful in developing their business in the amount of $12 \mathrm{KRP}$ or $24 \%$. It can be said that the empowerment through the establishment of coping the feminization poverty in Jalin Matra program in Tulusbesar Village was successful because the beneficiaries could be independent with a percentage of $70 \%$.

\section{References}

[1] Z. U. Nuha, "Pemberdayaan ekonomi keluarga melalui Penanggulangan Feminisasi Kemiskinan (PFK) terhadap peningkatan Ekonomi Keluarga Muslim di Kabupaten Blitar." Universitas Islam Negeri Maulana Malik Ibrahim, 2018.

[2] K. Erdianto, "Perempuan Indonesia Masih dalam Belenggu Diskriminasi," Kompas, 2016. [Online]. Available: http://nasional. kompas.com $/ \mathrm{read} / 2016 \quad / 08 / 21$ /16192911/perempuan.indonesia.masih.dalam.belenggu.diskriminasi. [Accessed: 28-Sep-2018].

[3] J. C. Ollenburger and H. A. Moore, "Sosiologi Wanita, terj," Budi Sucahyono dan Yan Sumaryana. Jakarta PT Rineka Cipta, 2002.

[4] N. Kurniawati, "Partisipasi Perempuan Pada Program Pemberdayaan Masyarakat (PRODAMAS) Di Kelurahan Banjar Melati Kecamatan Mojoroto Kota Kediri Jawa Timur." Universitas Airlangga, 2017.

[5] A. Utaminingsih, Gender dan Wanita Karir. Universitas Brawijaya Press, 2017.

[6] A. T. Sulistiyani, Kemitraan dan model-model pemberdayaan. Gava Media, 2004.

[7] H. M. A. Aziz, Dakwah pemberdayaan masyarakat: paradigma aksi metodologi. PT LKiS Pelangi Aksara, 2005. 
[8] B. Suyanto, Anatomi kemiskinan dan strategi penanganannya: fakta kemiskinan masyarakat pesisir, kepulauan, perkotaan dampak dari pembangunan di Indonesia. Intrans Publishing, 2013.

[9] A. Khomsan, A. H. Dharmawan, D. Sukandar, and H. Syarief, Indikator Kemiskinan dan Misklasifikasi Orang Miskin. Yayasan Pustaka Obor Indonesia, 2015.

[10] V. O. Soimin and W. Indrajid, "Pemberdayaan Masyarakat dan Pembangunan (Gagasan Manajemen Pengembangan Masyarakat untuk Memutus Mata Rantai Kemiskinan).” Malang: Intrans Publishing, 2014

[11] L. Soetrisno, Kemiskinan, perempuan, dan pemberdayaan. Penerbit Kanisius, 1997.

[12] K. D. Maani, "Teori ACTORS dalam Pemberdayaan Masyarakat," J. Demokr., vol. 10, no. 1, 2011 .

[13] B. Kurniawan and D. Mariana, Persembahan perempuan untuk desa: sebuah pendahuluan. Kerjasama IRE, TAF dan ACCESS Phase II, 2013.

[14] J. C. Scott, "Moral ekonomi petani," Jakarta LP3S, 2003.

[15] L. J. Moleong, Metodologi Penelitian Kualitatif. Bandung: Remaja Rosdakarya, 2000. 